\title{
IN VITRO MICROBIAL TIME-KILLING CURVE FOR NEWLY SYNTHESIZED AMINOACETYLENIC- 2-MERCAPTOBENZOTHIAZOLE COMPOUND
}

\author{
ASEEL ALSARAHNI ${ }^{1}$, ZUHAIR MUHI-ELDEEN ${ }^{2 *}$, ELHAM AL-KAISSI ${ }^{1}$, HIBA AL-MALLITI ${ }^{1}$
}

${ }^{1}$ Department of Pharmaceutics and Pharmaceutical Technology, Faculty of Pharmacy, University of Petra, Amman, Jordan, ${ }^{2}$ Department of Medicinal Chemistry and Pharmacognosy, Faculty of Pharmacy, University of Petra, Amman, Jordan

Email: zeldeen@uop.edu.jo

Received: 10 Jul 2017 Revised and Accepted: 21 Sep 2017

\section{ABSTRACT}

Objective: To determine the time needed for killing different types of microorganisms by a newly synthesized 2-mercapto-1,3-benzothiazole derivative in comparison to ciprofloxacin and fluconazole.

Methods: The minimum bactericidal concentration (MBC) and minimum fungicidal concentration (MFC) for 2-\{[4-(2,6-dimethylPiperidin-1-yl)but2-yn-1-yl]Sulfanyl\}-1,3-benzothiazole(AZ3) compound were determined, using the broth dilution method. The MBC and MFC dilutions were prepared. Broth cultures of Staphylococcus aureus (S. aureus), Bacillus subtilis (B. subtilis), Escherichia coli (E. coli), and Pseudomonas aeruginosa (P. aeruginosa) were incubated at $37{ }^{\circ} \mathrm{C}$ for $24 \mathrm{~h}$, and Candida albicans (C. albicans) was incubated at $25{ }^{\circ} \mathrm{C}$ for $48 \mathrm{~h}$. $0.1 \mathrm{ml}$ of each broth culture represent $1.5 \times 10^{6} \mathrm{CFU} / \mathrm{ml}$ was challenged with $9.9 \mathrm{ml}$ broth containing the MBC or MFC concentrations of the AZ3 compound. From each sample at different time intervals, $1 \mathrm{ml}$ was taken and added to $9 \mathrm{ml}$ of sterile distilled water, in order to neutralize the effect of AZ3. Serial dilution was done and a viable count was determined from the appropriate dilutions.

Results: The viability of the P. aeruginosa, E. coli, S. aureus, B. subtilis and $C$. albicans were killed within $3.5 \mathrm{~h}, 5 \mathrm{~h}, 24 \mathrm{~h}, 3 \mathrm{~h}$ and $5 \mathrm{~h}$ respectively. The time killing curves showed that AZ3 needed longer time for killing $S$. aureus than the time needed to kill $B$. subtilis. On the other hand, AZ3 needed a shorter time to kill $P$. aeruginosa, than the time needed to kill E. coli. In comparison with ciprofloxacin, AZ3 needed a shorter time to kill $P$. aeruginosa and E. coli, and the same time to kill B. subtilis, while it needed longer time than ciprofloxacin to kill $S$. aureus. In comparison with fluconazole, AZ3 with lower MFC than fluconazole needed longer time to kill $C$. albicans.

Conclusion: AZ3 showed promising antimicrobial killing activities, in compared with ciprofloxacin and fluconazole, which promoted our interest to investigate the time of killing needed for other 2-mercaptobenzothiazole derivatives against different types of microorganisms.

Keywords: 2-mercaptobenzothiazole derivatives, Alkylation, Mannich reaction, Time-kill curve

(c) 2017 The Authors. Published by Innovare Academic Sciences Pvt Ltd. This is an open-access article under the CC BY license (http://creativecommons.org/licenses/by/4.0/) DOI: http://dx.doi.org/10.22159/ijpps.2017v9i11.21245

\section{INTRODUCTION}

Molecules with benzothiazole (BTA) moiety have different biological activities [1]. Accordingly, 2-mercaptobenzothiazole (2-MBT) derivatives have a variety of applications [2]. 2-MBT was isolated as a natural product, from fermentation cultures of micrococcus species bacterial symbiont of the marine sponge Tedaniaignis [3]. 2-MBT consists of benzothiazole which is a heterocyclic compound includes benzene ring fused with 4,5-positions of the thiazole ring [4, 5], and the mercapto (thiol group) substituent at position 2 of thiazole ring that gives the compound antibacterial and anti-inflammatory activity [6]. 2MBT is prepared by reaction between 2-amino-thiophenol with refluxing carbon disulfide [6], in the presence of acetic anhydride [7]. Novel 4-substituted phenyl-3-chloro-1-[(benzothiazolythio) accetamidyl]-2-azetidinone derivatives were synthesized (fig. 1) These novel compounds were screened for their antibacterial and antifungal activities against $S$. aureus, $A$. niger, and $C$. albicans. The study showed that compound derivatives having $3-\mathrm{OH}-\mathrm{C}_{6} \mathrm{H}_{4}$ and $\mathrm{Cl}-$ $\mathrm{C}_{6} \mathrm{H}_{4}$ groups, promoted the activity against candida while compounds derivatives having $4-\mathrm{OH}-\mathrm{C}_{6} \mathrm{H}_{4}$ and $2-\mathrm{Cl}-\mathrm{C}_{6} \mathrm{H}_{4}$, at position 4 in the azetidinone nucleus are very effective against $S$. aureus and A. niger [8].

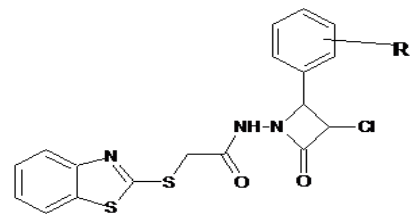

$\mathrm{R}=4-\mathrm{NO}_{2} / 3,4,5-\mathrm{Tri}-\mathrm{OCH}_{3} / 2-\mathrm{OH} / 3-\mathrm{OH} / 4-\mathrm{OH} / 2-\mathrm{OCH}_{3} / 4-\mathrm{OCH}_{3} / 2-$ $\mathrm{Cl} / 3-\mathrm{Cl} / 4-\mathrm{Cl}$

Fig. 1: 4-substituted phenyl-3-chloro-1-[(benzothiazolythio) accetamidyl]-2-azetidinone derivatives [8]
Kuchta et al. in 1989 carried out a research which involved 22 derivatives of 2-alkylthio-6-amino and 2-alkyl thio-6formamidobenzothiazole [9]. They were tested against 15 candida yeast strains, and against $A$. niger +with a suspension of spore free mycelium homogenate as inoculums. They found that no significant effect was observed against $A$. niger, The pathogenic species $C$ albicans and $C$. gnilliemondii. In another study, 3-(2-alkylsulfanyl-6benzothiazolylaminomethyl)-2-benzothiazolethiones were synthesized, by the reaction of 2-alkylsulfonyl-6aminobenzothiazoles with 3-hydroxy-2-benzoxazolethione in ethanol (fig. 2). New derivatives were tested against candida, researchers found that derivatives having the benzyl group at the second position of MBT ring demonstrated maximum inhibition of the oxygen evolution rate in spinach chloroplasts [10].

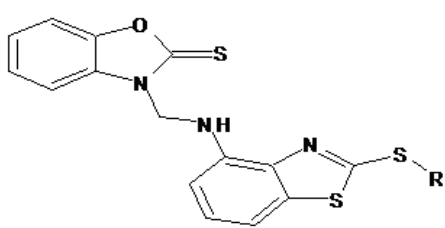

$\mathrm{R}=\mathrm{CH}_{3} / \mathrm{C}_{2} \mathrm{H}_{5} /$ allyl $/\left(\mathrm{CH}_{2}\right) \mathrm{CH}_{3} / \mathrm{CH}\left(\mathrm{CH}_{3}\right) \mathrm{C}_{2} \mathrm{H}_{5} /\left(\mathrm{CH}_{2}\right)_{4} \mathrm{CH}_{3}\left(\mathrm{CH}_{2}\right)_{5} \mathrm{CH}_{3} /($ $\left.\mathrm{CH}_{2}\right)_{6} \mathrm{CH}_{3} /\left(\mathrm{CH}_{2}\right)_{7} \mathrm{CH}_{3} /\left(\mathrm{CH}_{2}\right)_{8} \mathrm{CH}_{3} / \mathrm{CH}_{2} \mathrm{C}_{6} \mathrm{H}_{5}$

Fig. 2: 3-(2-alkylsulfanyl-6-benzothiazolylaminomethyl)-2benzothiazolethiones [9]

In this study, in vitro time exposure needed for killing different types of microorganisms by AZ3 was determined, and were compared to 
the time killing curves for ciprofloxacin and fluconazole against the same microorganisms. The main aim of this study is finding new promising 2-mercaptobenzothiazole derivatives, which have the ability to kill different microorganisms in competitive time compared to other drugs in the market.

\section{MATERIALS AND METHODS}

\section{Experimental}

\section{Chemicals}

2-mercaptobenzothiazole 97\%, propargyl bromide, cis-2,6dimethylpiperidine 98\%, all of them were purchased from (Sigma Aldrich, USA), magnesium sulphate anhydrous (Lonover, UK), potassium bromide $(\mathrm{KBr})$ (Scharlau, Spain), potassium carbonate anhydrous $\left(\mathrm{K}_{2} \mathrm{CO}_{3}\right)$ (Gainland Chemical Company (GCC, UK), paraformaldehyde polymer (BDH chemicals Ltd Poole, England), cuprous chloride LRG (east Anglia Chemicals Hadleighlpswich), acetonitrile 99.7\% (PanReAcSintesis)/(PanReAcQuimca SA, EU), 1,4dioxane HPLC/ACS (FULL Time, China), chloroform (stabilized with $0.5-1 \%$ ethanol) (TEDIA, USA), dimethyl sulfoxide (DMSO) (BBC Chemicals for lab, EU), diethyl ether (Lonover, England)/(RCL Labs can, Thailand), absolute ethanol 99.9\% (Super Chem, USA), acetone 99\% (Scharlau, Spain), distilled water (Ultra, Jordan).

\section{Instrumentation}

analytical balance with a precision $0.01 \mathrm{mg}$ (Phoenix instrument, USA), hot plate with magnetic stirrer (Dragon, China), rotary evaporator 0-100Kpa/0-700 mmHg (Rocker 600, Germany), Buchner funnel pump (Vacuubrand, Germany), melting point apparatus (Gallenkamp, USA), FT-IR spectrophotometer 7800 to 400 cm-1 (Evisa, Poland), DSC (Mettler Toledo, Int Co), UV-VIS (Evolution 160, USA), HPLC-UV (Finnigan Surveyor, USA), NMR 300 MHZ (Varian 300 MHZ, USA), NMR 500 MHZ (Varian 500 MHZ, USA), elemental analyzer with variation range $( \pm 4)$ (Euro Vector, Italy), autoclave machine (Rypa, Spain), incubator (EuroStar, EU), vortex mixer (Labinco, India), hot plate magnetic stirrer (Dragon, China), sterile tubes, sterile swabs (mWe, UK), micropipette (Oxford, USA).

\section{Synthesis}

\section{Synthesis of 2-(prop-2-yn-1-ylsulfanyl)-1,3-benzothiazole (AZ0)}

After the mixture of 2-MBT ( $5.01 \mathrm{~g}, 0.03 \mathrm{~mol})$, potassium carbonate anhydrous ( $3 \mathrm{~g}, 0.03 \mathrm{~mol})$ and $20-40 \mathrm{ml}$ acetonitrile (ACN) has been heated and stirred under reflux for $30 \mathrm{~min}$, the propargyl bromide (5 $\mathrm{ml}, 0.03 \mathrm{~mol}$ ) was added drop wise. The reaction mixture was heated and stirred under reflux for $2 \mathrm{~h}$. Then the mixture was filtrated and concentrated under reduced pressure to give a brown syrup. The crude product was extracted with $50 \mathrm{ml}$ chloroform and $50 \mathrm{ml}$ distilled water; chloroform layers were collected, dried over magnesium sulfate and evaporated under reduced pressure. The solid brownish crystals were weighed and characterized through DSC, UV-HPLC, FT-IR, ${ }^{\text {H }}$-NMR (fig. 3).

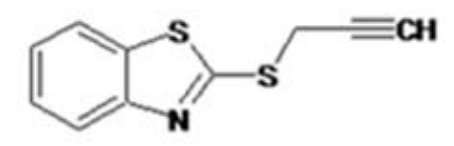

2-(Prop-2-yn-1-ylsulfanyl)-1,3-benzothiazole

Fig. 3: 2-(prop-2-yn-1-ylsulfanyl)-1,3-benzothiazole (AZ0)

Synthesis of 2-\{[4-(2,6-dimethylpiperidin-1-yl)but-2-yn-1-yl] sulfanyl\}-1,3-

\section{benzothiazole (AZ3)}

A mixture of 2-(prop-2-yn-1-yl sulfanyl)-1,3-benzothiazole (AZ0) ( $2.062 \mathrm{~g}, 0.01 \mathrm{~mol})$, paraformaldehyde $(0.5 \mathrm{~g}$ in excess), cyclic amine (2,6-dimethyl piperidine) and a catalytic amount of cuprous chloride in 1,4-dioxane $(25 \mathrm{ml})$ was stirred at room temperature, for $10 \mathrm{~min}$ then was heated and stirred under reflux at $70-75^{\circ} \mathrm{C}$ for three $\mathrm{h}$. The reaction mixture was filtrated and concentrated under reduced pressure, to give a brown syrup which was dissolved in diethyl ether, filtrated and concentrated under reduced pressure. The final products was 2-\{[4-(2,6-dimethylpiperidin-1-yl)but-2-yn-1-yl] sulfanyl\}-1,3-benzothiazole (AZ3). The title compound AZ3 was synthesized by Mannich reaction in $2.5 \mathrm{~g}$, yield $76.22 \%$, mp: 48.62 ${ }^{\circ} \mathrm{C}$, UV-HPLC retention time: $2.167 \mathrm{~min}$, FT-IR $(\mathrm{KBr} \mathrm{cm}-1)$ : C-H stretching aromatic (3080.477 cm-1, $2923.556 \mathrm{~cm}-1), \mathrm{C}-\mathrm{H}$ stretching tertiary amine $(2850.274 \mathrm{~cm}-1,2788.563 \mathrm{~cm}-1, \mathrm{C}=\mathrm{C}$ stretching aromatic $(1673.909 \mathrm{~cm}-1), \mathrm{C}=\mathrm{N}$ stretching thiazole $(1590.985 \mathrm{~cm}-1,1432.851 \mathrm{~cm}-$ 1), C-N stretching $3^{\circ}$ aromatic $(1373.168 \mathrm{~cm}-1)$, C-N stretching tertiary cyclic amine (12226.433 cm-1), C-H out of plane bending aromatic (865.882 cm-1), C-S stretching $(717.39 \mathrm{~cm}-1,624.823 \mathrm{~cm}-1), 1 \mathrm{H}-\mathrm{NMR}$ (DMSO d6): $\delta$; four types of cyclic amine protons: $0.75 \mathrm{ppm}$ (doublet, type A, 6H), 0.95 ppm (sextet, type B, $2 \mathrm{H}$ ), 1.2-1.35 ppm (quartet, type $\mathrm{C}$, $4 \mathrm{H}), 2$ ppm (quintet, type D, 2H), 3.4 ppm (singlet, C-CH2-N, 2H), 4.2 ppm (singlet, $\mathrm{S}-\mathrm{CH} 2 \mathrm{C}, 2 \mathrm{H}$ ), four types of aromatic protons: $7.35 \mathrm{ppm}$ (triplet type A, 2H), $7.45 \mathrm{ppm}$ (triplet, type B, 2H), $7.85 \mathrm{ppm}$ (doublet, type C, 1H), 8 ppm (doublet, type D, 1H).

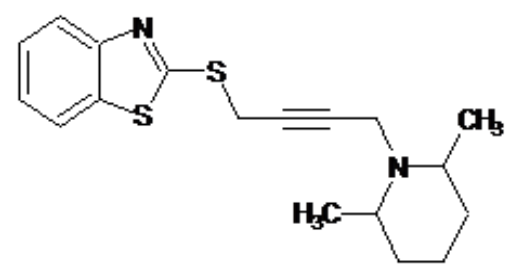

Fig. 4: Synthesis of 2-\{[4-(2,6-dimethylpiperidin-1-yl)but-2-yn1-yl] sulfanyl\}-1,3-benzothiazole (AZ3)

\section{Culture media}

Muller hinton agar (MHA) (Mastgrp Ltd, UK)/(Himedia, India), muller hinton broth (MHB) (Mastgrp Ltd, UK), sabourauds dextrose agar (SDA) (Mastgrp Ltd, UK), sabourauds dextrose broth (SDB) (Himedia, India), dimethyl sulfoxide (DMSO) (BBC Chemicals for lab, $\mathrm{EU})$, distilled water (Ultra, Jordan).

\section{Microorganisms}

Staphylococcus aureus (S. aureus ATCC 6538), Bacillus subtilis (B. subtilis ATCC 6633), Pseudomonas aeruginosa (P. aeruginosa ATCC 9027), Escherichia coli (E. coli ATCC 8739), Candida albicans ( $C$. albicans ATCC 10231). All these bacterial strains were obtained from Dar Al Dawa (Na'ur, Jordan).

\section{Determination of microbial time kill curves for AZ3}

The minimum inhibitory concentration (MIC) and MBC for AZ3 were determined firstly. The synthesized compound (AZ3) was diluted out in the series of twofold dilutions, in a liquid growth medium dispensed in test tubes $[11,12]$. The AZ3 stock solution has to be at least $1000 \mu \mathrm{g} / \mathrm{ml}$ [12]. Accordingly, AZ3 stoke solution was prepared in $1000 \mu \mathrm{g} / \mathrm{ml}$ in $10 \mathrm{ml}$ DMSO, this solution was diluted serially in MHB for bacteria and SDB for fungi, to give concentrations ranging from $500-7.81 \mu \mathrm{g} / \mathrm{ml}$. The final volume of the compound dilutions in each tube was $5 \mathrm{ml}$. To these tubes, $0.1 \mathrm{ml}$ of the overnight culture was added. Positive control tube contained $5 \mathrm{ml}$ of sterile broth and $0.1 \mathrm{ml}$ of microbial culture, while the negative control tube contained $5 \mathrm{ml}$ of the tested compound dilution in sterile broth.

The tubes were incubated at $37^{\circ} \mathrm{C}$ for $24 \mathrm{~h}$ for bacteria, and at $25^{\circ} \mathrm{C}$ for $48 \mathrm{~h}$ for fungi. The MIC was determined by comparison the turbidity of each concentration tube with the turbidity of the positive control tube; MIC tube is the lowest concentration of the compound in which no turbidity was observed [13]. To determine MBC and MFC, the MIC tube and the tubes with dilutions preceded were sub-cultured onto agar plates, the plates were incubated at 37 ${ }^{\circ} \mathrm{C}$ for $24 \mathrm{~h}$ for bacteria, and at $25{ }^{\circ} \mathrm{C}$ for $48 \mathrm{~h}$ for fungi. The lowest concentration tube that gave no growth was the MBC or MFC. Broth 
dilution test was designed to allow for statistical analysis and was performed in triplicates.

Time exposure viability test for AZ3 was carried out, to assess the killing ability rate of AZ3 within a given contact time. The MBC and MFC concentrations were prepared for compound AZ3 using sterile broth. The microbial cultures were prepared and incubated at $37^{\circ} \mathrm{C}$ for $24 \mathrm{~h}$ for bacteria and at $25{ }^{\circ} \mathrm{C}$ for $48 \mathrm{~h}$ for fungi. $0.1 \mathrm{ml}$ of each culture with definite inoculum sizes were challenged with $9.9 \mathrm{ml}$ of $\mathrm{MBC} / \mathrm{MFC}$ concentrations for the AZ3 compound.

Then $1 \mathrm{ml}$ was taken from the sample, at different time intervals as shown in (table 1), and added to $9 \mathrm{ml}$ of sterile distilled water, to neutralize the AZ3 activity (this step was enough to neutralize as primarily detected). Serial dilution using sterile distilled water was done, and the viable count was determined from the appropriate dilutions.

Table 1: Time intervals used for bacterial killing curve

\begin{tabular}{|c|c|c|c|c|c|c|}
\hline \multirow{2}{*}{$\begin{array}{l}\text { Microorganism } \\
\text { S. aureus }\end{array}$} & \multicolumn{6}{|c|}{ Time intervals (h) } \\
\hline & 1.5 & 2.5 & 3.5 & 4.5 & 20 & 24 \\
\hline B. subtilis & 0.5 & 1 & 2 & 3 & 4 & 5 \\
\hline E. coli & 1 & 1.5 & 2 & 5 & - & - \\
\hline P. aeruginosa & 1.5 & 2.5 & 3.5 & 4.5 & 5.5 & - \\
\hline C. albicans & 0.5 & 1 & 2 & 2.5 & 3 & 5 \\
\hline
\end{tabular}

\section{RESULTS}

\section{Minimum inhibitory concentrations results}

The newly synthesized compound AZ3 showed activity against all types of microorganisms tested (table 2), the minimum inhibitory concentrations (MIC), and minimum bactericidal/fungicidal concentrations (MBC/MFC) were measured (table 2).

\section{Microbial time-killing curve results}

The time exposure viability curve for the addition of $0.1 \mathrm{ml} P$. aeruginosa ATCC 9027 culture, with a viable count of $\left(2.47 \times 10^{7}\right)$ to
$\mathrm{AZ3}$ at $250 \mu \mathrm{g} / \mathrm{ml}$ dilution was demonstrated in fig. 5 . The 5 log cycle reductions were detected, the curve shows that the bacterial count decreased rapidly over $1 \mathrm{~h}$. Then over $1.5 \mathrm{~h}$, the count of bacteria decreased slowly. The viability of the P. aeruginosa abolished within $3.5 \mathrm{~h}$. accordingly, the LT $90 \%$ value (time at which $90 \%$ of the original population were killed by the antimicrobial agent) for this experiment was approximately in the period between 2.5 and $3.5 \mathrm{~h}$. In the time-killing test for ciprofloxacin against $P$. aeruginosa, the 7 $\log$ cycle reductions were detected, the curve shows that the count of bacteria decreased rapidly within the first $0.5 \mathrm{~h}$, then the count decreased slowly within the $4 \mathrm{~h}$. The viability of the P. aeruginosa was abolished within $5 \mathrm{~h}$.

Table 2: MIC and MBC of AZ3

\begin{tabular}{lllll}
\hline Microorganisms & P. aeruginosa & E. coli & S. aureus & B. subtilis \\
\hline MIC $(\mu \mathrm{g} / \mathrm{ml})$ & 125 & 250 & 125 & 62.5 \\
$\operatorname{MBC}(\mu \mathrm{g} / \mathrm{ml})$ & 250 & 500 & 500 & 125 \\
\hline
\end{tabular}

Values are the mean (n=3), AZ3: 2-\{[4-(2, 6-dimethylpiperidin-1-yl) but-2-yn-1-yl] sulfanyl\}-1,3-benzothiazole.

Table 3: Bacterial time-killing of AZ3 against P. aeruginosa ATCC 9027

\begin{tabular}{llllll}
\hline Microorganism & P. aeruginosa & & & \\
\hline Time $(\mathrm{h})$ & 0 & 1.5 & 2.5 & 3.5 & 4.5 \\
Count $(\mathrm{CFU} / \mathrm{ml})$ & $2.47 \times 10^{7}$ & $6.8 \times 10^{3}$ & $1.4 \times 10^{3}$ & 0 & 0 \\
Log $(\mathrm{CFU} / \mathrm{ml})^{*}$ & $7.39 \pm 0.61$ & $3.83 \pm 0.17$ & $3.15 \pm 0.85$ & 0 & 0 \\
\hline
\end{tabular}

*Values are the mean \pm SD (n=3), SD: standard deviation, CFU: colony forming unit, AZ3: 2-\{[4-(2,6-dimethylpiperidin-1-yl)but-2-yn-1-yl]sulfanyl\}1,3-benzothiazole.

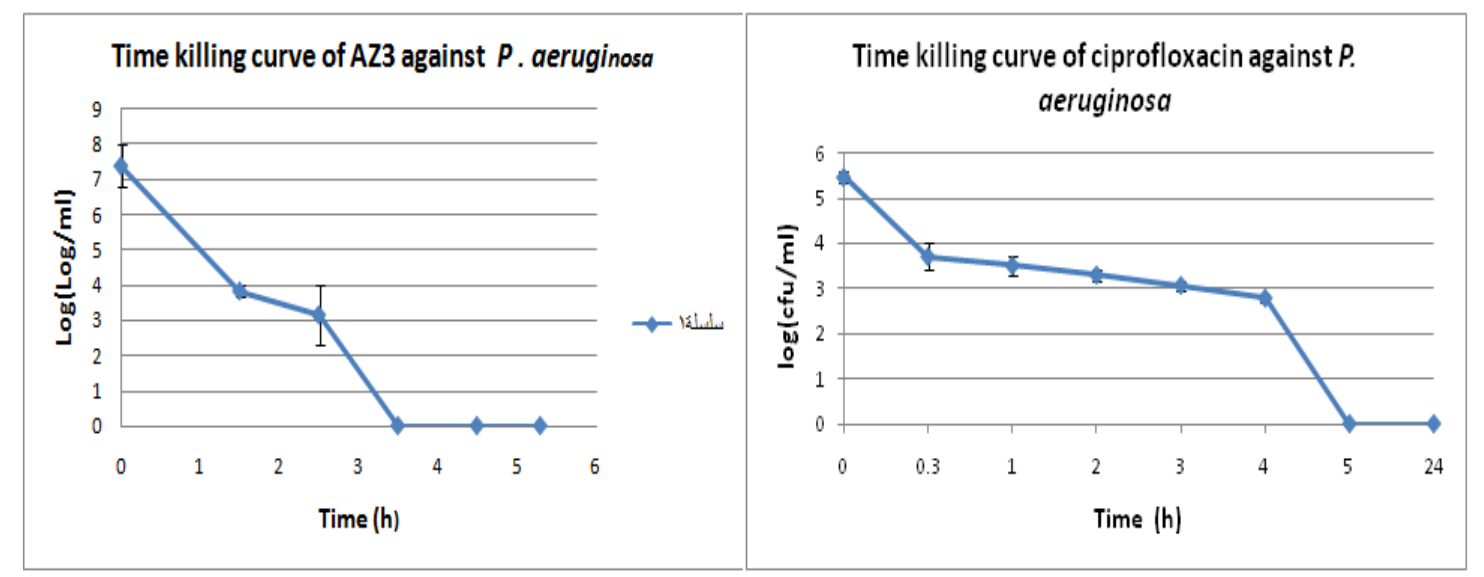

Fig. 5: Time exposure viability curve for addition of compound AZ3 and ciprofloxacin, at MBC ( $250 \mu \mathrm{g} / \mathrm{ml})$ to culture of $P$. aeruginosa ATCC 9027 
Values are the mean $\pm \mathrm{SD}(\mathrm{n}=3)$, AZ3: 2 - $\{[4$-(2,6-dimethylpiperidin-1yl)but-2-yn-1-yl] sulfanyl $\}-1,3$-benzothiazole, CFU: colony forming unit, time (X axis): time intervals needed for killing $P$. aeruginosa, $\log (\mathrm{CFU} / \mathrm{ml}$ ) (Y axis): viability of $P$. aeruginosa at different times.

The time exposure viability curve for the addition of $0.1 \mathrm{ml}$ of $E$. coli ATCC 8739 culture, with a viable count of $\left(1.42 \times 10^{7}\right)$ to AZ3 at 500 $\mu \mathrm{g} / \mathrm{ml}$ dilution was demonstrated in fig. 6 . The 4 log cycle reductions were obtained in approximately $5 \mathrm{~h}$. The count of bacteria decreased quickly over $1 \mathrm{~h}$, then the count of bacteria decreased slowly over the next $1 \mathrm{~h}$. The viability of $E$. coli was abolished within $5 \mathrm{~h}$. accordingly, the LT $90 \%$ value for this experiment was approximately in the period between $2-5 \mathrm{~h}$.

In The time-killing test for ciprofloxacin against $E$. coli, The $5 \log$ cycle reductions were detected. The curve shows that the count of bacteria decreased within the first $0.5 \mathrm{~h}$, then the count decreased slowly within the $4 \mathrm{~h}$. The viability of $E$. coli was abolished within $5 \mathrm{~h}$.

Table 4: Bacterial time-killing of AZ3 against E. coli 8739

\begin{tabular}{lllll}
\hline Microorganism & E. coli & & \\
\hline Time (h) & $\mathbf{0}$ & $\mathbf{1}$ & $\mathbf{1 . 5}$ & $\mathbf{2}$ \\
\hline Count (CFU/ml) & $1.42 * 10^{7}$ & $3.4 \times 10^{3}$ & $1.63 \times 10^{3}$ & $3.0 \times 10^{2}$ \\
Log (CFU/ml)* & $7.15 \pm 0.85$ & $3.53 \pm 0.47$ & $3.21 \pm 0.79$ & 0 \\
\hline
\end{tabular}

*Values are the mean \pm SD (n=3), SD: standard deviation, CFU: colony forming unit, AZ3: 2-\{[4-(2,6-dimethylpiperidin-1-yl)but-2-yn-1-yl]sulfanyl\}1,3-benzothiazole.

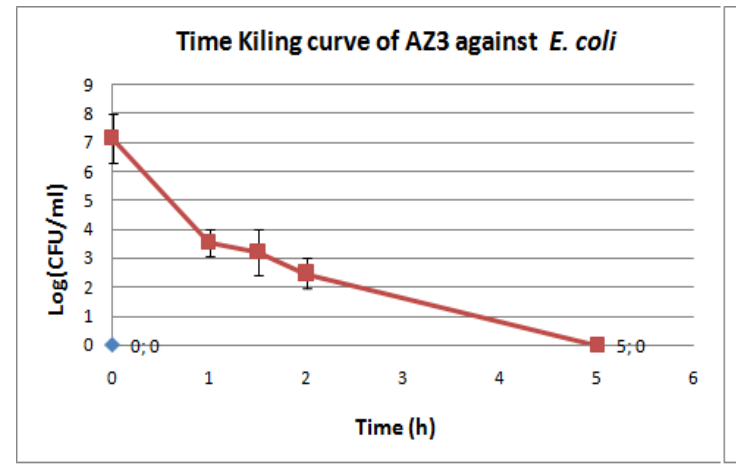

\section{Time killing curve of ciprofloxacin against E.coli}

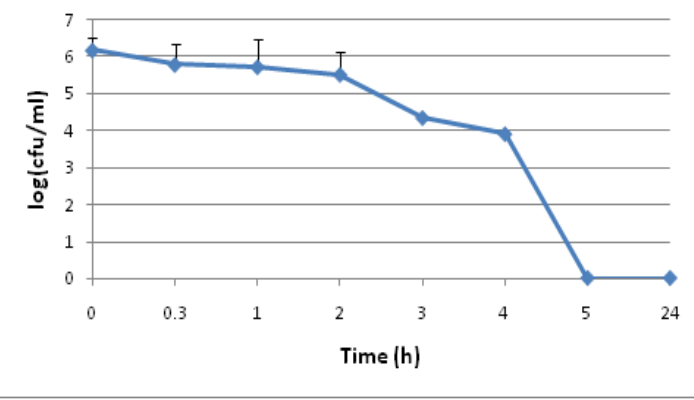

Fig. 6: Time exposure viability curve for addition of compound AZ3 and ciprofloxacin, at MBC (500 $\mu \mathrm{g} / \mathrm{ml})$ and $(125 \mu \mathrm{g} / \mathrm{ml})$ respectively to culture of $E$. coli ATCC 8739

Values are the mean $\pm \mathrm{SD}(\mathrm{n}=3), \mathrm{AZ3}: 2-\{[4-(2,6$-dimethylpiperidin-1yl) but-2-yn-1-yl] sulfanyl\}-1,3-benzothiazole, CFU: colony forming unit, time (X-axis): time intervals needed for killing E. coli, Log (CFU/ml) (Y-axis): viability of microorganisms at different times.

The time exposure viability curve for the addition of $0.1 \mathrm{ml}$ of $S$. aureus ATCC 6538 culture, with a viable count of $\left(1.76 \times 10^{8}\right)$ to 500 $\mu \mathrm{g} / \mathrm{mlAZ3}$ dilution was demonstrated in fig. 7 . The 6 log cycle reductions were obtained in approximately $24 \mathrm{~h}$. The count of bacteria decreased quickly after $1.5 \mathrm{~h}$, then the count of bacteria decreased slowly over $18.7 \mathrm{~h}$. The viability of $S$. aureus was abolished within $24 \mathrm{~h}$. Accordingly, the LT 90\% value for this experiment was approximately in the period between $20 \mathrm{~h}$ and $24 \mathrm{~h}$. AZ3 needed the longer time of exposure to kill all of the original $S$. aureus population.

In the time-killing test for ciprofloxacin against S. aureus, the 7 log cycle reductions were detected, the curve shows that the count of bacteria decreased slowly within the first $2 \mathrm{~h}$, then it decreases rapidly between 2 to $3 \mathrm{~h}$. The viability of $S$. aureu was abolished within $5 \mathrm{~h}$.

Table 5: Bacterial time-killing of AZ3 against S. aureus 6539

\begin{tabular}{|c|c|c|c|c|c|c|c|}
\hline Microorganism & S. aureus & & & & & & \\
\hline Time (h) & Zero & 1.5 & 2.5 & 3.5 & 4.5 & 20 & 24 \\
\hline Count $(\mathrm{CFU} / \mathrm{ml})$ & $1.76 \times 10^{8}$ & $1.34 \times 10^{6}$ & $1.29 \times 10^{6}$ & $3.4 \times 10^{5}$ & $5.9 \times 10^{4}$ & $2.8 \times 10^{4}$ & 0 \\
\hline$(\mathrm{Log} \mathrm{CFU} / \mathrm{ml})^{*}$ & $8.25 \pm 0.75$ & $6.13 \pm 0.87$ & $6.11 \pm 0.89$ & $5.53 \pm 0.47$ & $4.77 \pm 0.23$ & $4.45 \pm 0.55$ & 0 \\
\hline
\end{tabular}

*Values are the mean \pm SD (n=3), SD: standard deviation, CFU: colony forming unit, AZ3: 2-\{[4-(2,6-dimethylpiperidin-1-yl)but-2-yn-1-yl]sulfanyl\}1,3-benzothiazole.

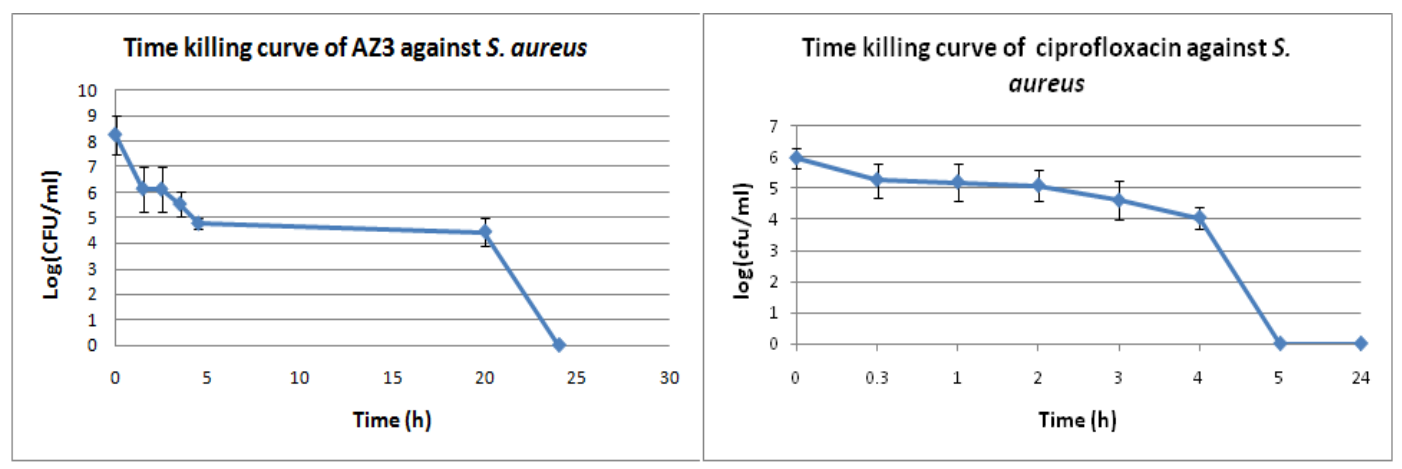

Fig. 7: Time exposure viability curve for addition of compound AZ3 and ciprofloxacin at MBC $(250 \mu \mathrm{g} / \mathrm{ml})$ to culture of $S$. aureus ATCC 6538 
Values are the mean $\pm S D(n=3), A Z 3: 2-\{[4-(2,6$-dimethyl piperidin-1yl) but-2-yn-1-yl]sulfanyl\}-1,3-benzothiazole, CFU: colony forming unit, time (X-axis): time intervals needed for killing $S$. aureus, Log (CFU/ml) (Y-axis): viability of $S$. aureus at different times.

The time exposure viability curve for the addition of $0.1 \mathrm{ml}$ of $B$. subtilis ATCC 6633 culture, with a viable count $1.08 \times 10^{3} \mathrm{CFU} / \mathrm{ml}$ to AZ3 at $125 \mu \mathrm{g} / \mathrm{ml}$ dilution was demonstrated in fig. 8. The 6 log cycle reductions were obtained in approximately $5 \mathrm{~h}$. Surprisingly, the count of bacteria increased over $2 \mathrm{~h}$, then the count of bacteria decreased sharply over the next $1 \mathrm{~h}$. The viability of $B$. subtilis was abolished within $3 \mathrm{~h}$. The LT $90 \%$ value for this experiment was approximately in the period between 2 to $3 \mathrm{~h}$. In

The time-killing test for ciprofloxacin against B. subtilis, the 7 log cycle reductions were detected, the curve shows that the count of bacteria decreased slowly within the first $2 \mathrm{~h}$. The viability of $B$. subtilis was abolished within $3 \mathrm{~h}$

Table 6: Bacterial time-killing of AZ3 against B. subtilis 6633

\begin{tabular}{|c|c|c|c|c|c|c|c|}
\hline Microorganism & B. subtilis & & & & & & \\
\hline Time & 0 & 0.5 & 1 & 2 & 3 & 4 & 5 \\
\hline Count (CFU/ml) & $1.08 \times 10^{3}$ & $2.44 \times 10^{3}$ & $4.6 \times 10^{4}$ & $6.00 \times 10^{4}$ & 0 & 0 & 0 \\
\hline $\log (\mathrm{CFU} / \mathrm{ml})^{*}$ & $3.03 \pm 0.97$ & $3.39 \pm 0.61$ & $4.66 \pm 0.34$ & $4.78 \pm 0.22$ & 0 & 0 & 0 \\
\hline
\end{tabular}

$\log (\mathrm{CFU} / \mathrm{ml})^{*}$

$3.03 \pm 0.97$

$2.44 \times 10^{3}$
$3.39 \pm 0.61$

$4.66 \pm 0.34$

$4.78 \pm 0.22$

*Values are the mean \pm SD $(n=3)$, SD: standard deviation, CFU: colony forming unit, AZ3: 2-\{[4-(2,6-dimethylpiperidin-1-yl)but-2-yn-1-yl]sulfanyl\}1,3-benzothiazole.

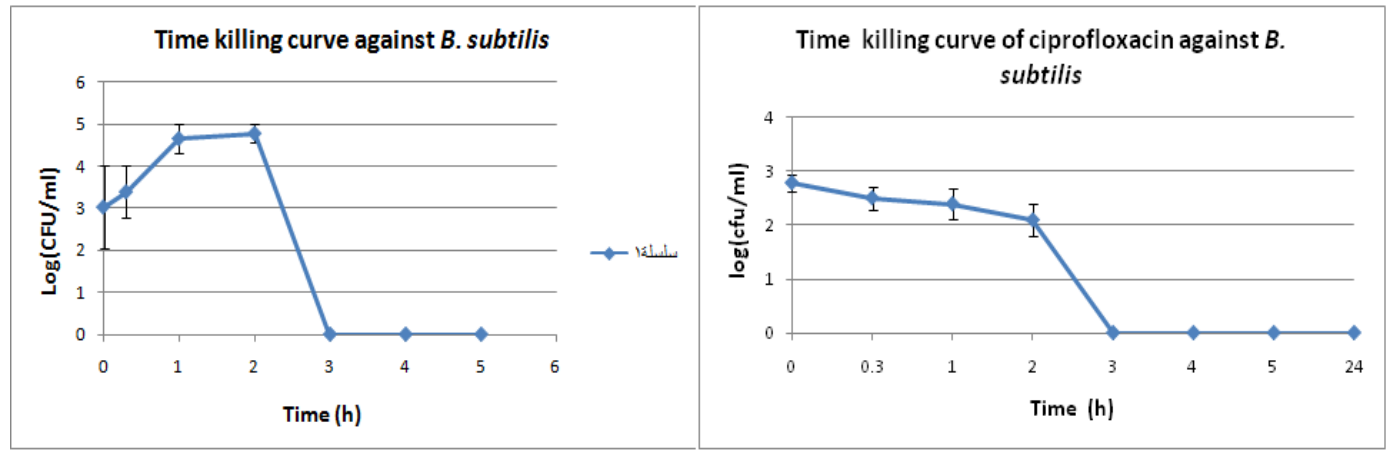

Fig. 8: Time exposure viability curve for addition of compound AZ3 and ciprofloxacin, at MBC (125 $\mu \mathrm{g} / \mathrm{ml})$ and $(250 \mu \mathrm{g} / \mathrm{ml}) \mathrm{respectively}$ to culture of B. subtilis ATCC 6633

Values are the mean $\pm S D(n=3)$, AZ3: $2-\{[4-(2,6$-dimethylpiperidin-1yl)but-2-yn-1-yl]sulfanyl\}-1,3-benzothiazole, CFU: colony forming unit, time (X-axis): time intervals needed for killing B. subtilis, Log (CFU/ml) (Y): viability B. subtilis at different times.

The time exposure viability curve for the addition of $0.2 \mathrm{ml}$ culture of $C$. albicans ATCC 10231, with a viable count $3.0 \times 10^{6} \mathrm{CFU} / \mathrm{ml}$ to AZ3 at 250 $\mu \mathrm{g} / \mathrm{ml}$ dilution was demonstrated in fig. 9. The $6 \log$ cycle reductions were obtained in approximately $5 \mathrm{~h}$. The count of fungi decreased over
$30 \mathrm{~min}$, then the count of fungi increased slowly over the next $30 \mathrm{~min}$. After $2.5 \mathrm{~h}$, the count of fungi decreased slowly. The viability of microorganism decreased rapidly within the next $2 \mathrm{~h}$. Accordingly, $C$. albicans was totally killed within $5 \mathrm{~h}$. The LT $90 \%$ value for this experiment was approximately in the period between 3-5 $\mathrm{h}$. In the timekilling test for fluconazole against $C$. albicans, the $6 \log$ cycle reductions were detected, the curve shows that the count of bacteria decreased slowly within the first $45 \mathrm{~min}$, then it decreased rapidly between 45-60 min. The viability of C. albicans was abolished within $3 \mathrm{~h}$.

Table 7: Bacterial time-killing of AZ3 against C. albicans ATCC 10231

\begin{tabular}{lllllll}
\hline microorganism & C. albicans & & & & & \\
\hline Time (h) & $\mathbf{0}$ & $\mathbf{0 . 5}$ & $\mathbf{1}$ & $\mathbf{2}$ & $\mathbf{2 . 5}$ & $\mathbf{3}$ \\
\hline Count $(\mathrm{CFU} / \mathrm{ml})$ & $3.0 \times 10^{6}$ & $1.98 \times 10^{4}$ & $1.7 \times 10^{5}$ & $1.32 \times 10^{5}$ & $1.21 \times 10^{5}$ & $8.6 \times 10^{4}$ \\
$\log (\mathrm{CFU} / \mathrm{ml})^{*}$ & $6.48 \pm 0.52$ & $4.30 \pm 0.7$ & $5.23 \pm 0.77$ & $5.12 \pm 0.88$ & $5.10 \pm 0.9$ & $4.93 \pm 0.07$ \\
\hline
\end{tabular}

*Values are the mean \pm SD (n=3), SD: standard deviation, CFU: colony forming unit, AZ3: 2-\{[4-(2,6-dimethylpiperidin-1-yl)but-2-yn-1-yl]sulfanyl\}1,3-benzothiazole.
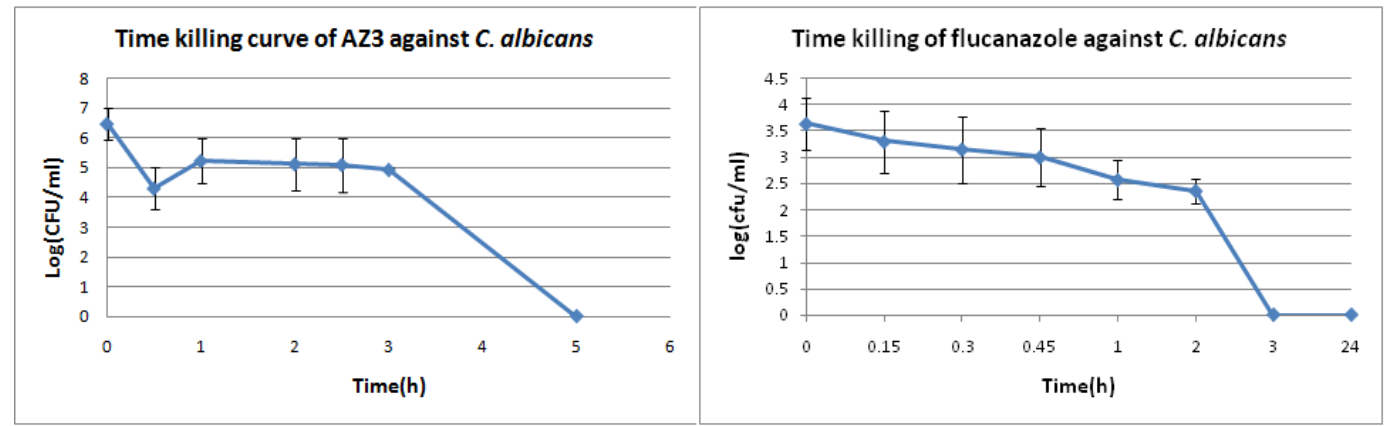

Fig. 9: Time exposure viability curve for addition of compound AZ3 and fluconazole, at MFC (250 $\mu \mathrm{g} / \mathrm{ml})$ and $(500 \mu \mathrm{g} / \mathrm{ml})$ respectively to culture of $C$. albicans ATCC 10231 
Values are the mean $\pm \mathrm{SD}(\mathrm{n}=3), \mathrm{AZ} 3: 2-\{[4-(2,6$-dimethyl-piperidin1-yl)but-2-yn-1-yl]sulfanyl $\}-1,3$-benzothiazole, CFU: colony forming unit, time (X-axis): time intervals needed for killing C. albicans, Log (CFU/ml) (Y-axis): viability of $C$. albicans at different times.

\section{DISCUSSION}

The time-killing curve test showed that, 2-\{[4-(2,6-dimethyl Piperidin-1-yl)but-2-yn-1-yl]Sulfanyl $\}-1,3$-benzothiazole (AZ3) needed much longer time, to kill $S$. aureus in comparing with the time needed to kill B. subtilis at MBC value $250 \mu \mathrm{g} / \mathrm{ml}$; in which AZ3 needed $20-24 \mathrm{~h}$ to kill $S$. aureus and $2-3 \mathrm{~h}$ to kill B. subtilis. The differences in potency and efficacy of the newly synthesized compound, against $S$. aureus and $B$. subtilis may attribute to the high resistance and the high virulence nature of $S$. aureus [14]. On the other hand, ciprofloxacin needed $5 \mathrm{~h}$ and $3 \mathrm{~h}$ to kill $S$. aureus and $B$. subtilis respectively, at MBC value $250 \mu \mathrm{g} / \mathrm{ml}$. The time-killing curve for $B$. subtilis showed that the count of bacteria increased over the 2 $\mathrm{h}$ after exposure to AZ3, then the viable count of bacteria dropped sharply and became zero, this result may attribute to the endospore germination of B. subtilis; in which the endospore germination might increase the viable count of $B$. subtilis during the first $2 \mathrm{~h}$ exposure. AZ3 needed a shorter time to kill $P$. aeruginosa than the time needed to kill $E$. coli, at MBC value $250 \mu \mathrm{g} / \mathrm{ml}$; whereas AZ3 needed $5 \mathrm{~h}$ and $3.5 \mathrm{~h}$ to kill E. coli and P. aeruginosa respectively. These results may be attributed to the good permeability of the synthesized compound by the dual pathway (porins and phospholipids bilayer) through $P$. aeruginosa outer membrane and the lacking porins in $E$. coli outer membrane may cause decrease in drug accumulation inside bacteria that use only one pathway for entering bacteria [11]. AZ3 killed $C$. albicans within $5 \mathrm{~h}$, whereas fluconazole killed C. albicans within $3 \mathrm{~h}$.

\section{CONCLUSION}

The newly synthesized 2-\{[4-(2, 6-dimethylPiperidin-1-yl) but-2-yn-1yl] Sulfanyl\}-1, 3-benzothiazole (AZ3) showed a promising killing activity, against $P$. aeruginosa, E. coli, and C. albicans. This study may promote further expansion of 2-mercaptobenzothiazole derivatives bearing dimethyl piperidin and other cyclic amine moieties, which may lead to compound with potent and broader antimicrobial activities.

\section{ACKNOWLEDGMENT}

The authors would like to thank the University of Petra/Faculty of Pharmacy for providing the necessary facilities to carry out this work.

\section{AUTHORS CONTRIBUTION}

Msc. Aseel Alsarahni was responsible for the laboratory work and writing the paper draft

Prof. Zuhair Muhi-Eldeen is the chief author, supervised the synthesis steps

Prof. Elham Al-Kaissi was responsible for writing and supervised the microbiology part.
Msc. Heba was responsible for part of the laboratory work.

\section{CONFLICT OF INTERESTS}

The authors have declared no conflict of interest

\section{REFERENCES}

1. Ali R, Siddiqui N. Biological aspects of emerging benzothiazoles: a short review. J Chem 2013:1-12. http://dx.doi.org/ $10.1155 / 2013 / 345198$

2. Ali S. Synthesis and preliminary antibacterial study of new 2mercapto-1,3-benzothiazole derivatives with expected biological activity. Am J Pharmacol Sci 2013;13:119-24.

3. Azam MA, Suresh B. Biological activities of 2mercaptobenzothiazole derivatives: a review. Sci Pharm 2012;80:789-823.

4. Bujdakova H, Muckova M. Antifungal activity of a new benzothiazole derivative against candida in vitro and in vivo. Int J Antimicrob Agents 1994;4:303-8.

5. NCCL. National committee for clinical laboratory standards for antimicrobial disk susceptibility testing (M02-A11) Wayne, PA: NCCL; 2012. p. 32.

6. Desai K, Desai K. Rapid and efficient synthesis of some biological active 2-azetidinones under microwave irradiation. Indian J Chem 2005;44B:2093-6.

7. Ericsson J, Sherris J. Antibiotic sensitivity testing: report of an international collaborative study. Acta Pathol Microbiol Scand 1971;217:1-90.

8. Feng-Ling $\mathrm{W}$, Waleed MH, Benjamin PR, Ross PM. 2Mercaptobenzothiazole and its derivatives: syntheses, reactions and applications. Curr Organ Chem 2012;16:1555-80.

9. Khokra SL, Arora K, Mehta H, Aggarwal A, Yadav M. ChemInform abstract: common methods to synthesize benzothiazole derivatives and their medicinal significance. Chin Chem Inform 2011;42. Doi:10./chin.201142237.

10. Padalkar VS, Borse BN, Gupta VD, Phatangare KR, Patil VS, Umape PG, et al. Synthesis and antimicrobial activity of novel 2substituted benzimidazole, benzoxazole and benzothiazole derivatives. Arab J Chem 2011;9:S1125-30.

11. Stierle AA, Cardellina JH, Singleton FL. Benzothiazoles from a putatitve bacterial symbiont of the marine sponge Tedania ignis. Tetrahedron Lett 1991;32:4847-8.

12. Jayaprakash R, Kumar SHA, Hemalatha S, Easwaramoorthy D. Synthesis, characterization, quantitative structure-activity relationship, docking, antibacterial activity, and brine shrimp lethal studies on L-phenylalanine schiff bases. Asian J Pharm Clin Res 2016;9:203-8.

13. Das S, Dewan N, Das KJ, Kalita D. Preliminary phytochemical, antioxidant and antimicrobial studies of flacouttia jangomas fruits. Int J Chem Pharm Res 2017;9:86-91.

14. Patil NR, Gadagil SA. Performance of CHROM agar medium and conventional method for detection of methicillin-resistant Staphylococcus aureus. Asian J Pharm Clin Res 2016;9:136-9. 